International Journal of Instruction e-ISSN: 1308-1470 • www.e-iji.net

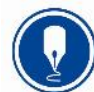

January $2022 \bullet$ Vol.15, No.1

p-ISSN: 1694-609X

pp. 489-508

Article submission code:

20210124101915
Received: 24/01/2021

Revision: 09/07/2021
Accepted: 03/08/2021

OnlineFirst: 29/10/2021

\title{
Appropriate Internet Use Behavior (AIUB) of Thai Preservice Teachers: A Hierarchical Linear Model (HLM) Analysis
}

\section{Paitoon Pimdee}

Assoc. Prof., School of Industrial Education and Technology, King Mongkut's Institute of Technology Ladkrabang (KMITL), Bangkok, Thailand, paitoon.pi@kmitl.ac.th

\section{Punnee Leekitchwatana}

Assoc. Prof., School of Industrial Education and Technology, King Mongkut's Institute of Technology Ladkrabang (KMITL), Bangkok, Thailand, punnee.le@kmitl.ac.th

This study reports on Thai preservice teachers' appropriate Internet use behavior (AIUB) in 30 tertiary institutions across Thailand. The sample used both multistage random sampling and stratified random sampling to select the study's 1,800 participants which were grouped into two academic disciplines related to information and communications technology (ICT) and non-ICT disciplines. A questionnaire was used to identify both the internal and external factors, in which item reliability was judged to be $0.83-0.92$. The HLM 7 software program was used to analyze the two-tiered linear model on pre-service teacher AIUB. Three types of two-tier models were evaluated, one with a dependent variable, a second model with student-level independent variables, and a third model using independent variables at both the student level and the school level. Data were analyzed employing average statistics $(\bar{x})$ and standard deviation using IBM SPSS Version 21 software. The HLM 7 software was used for the analysis of the three HLMs classified by ICT and non-ICT disciplines. Results revealed that each preservice teacher's abilities, characteristics, home/family situation, and their friends/classmates were predictive parameters that influenced the models, confirming the importance of these four variables in positively influencing preservice teacher AIUB.

Keywords: ICT preservice teachers, inappropriate internet use behavior, non-ICT preservice teachers, student-teachers, Thailand

\section{INTRODUCTION}

Today, information communications technology (ICT), social media, and the Internet have become tools most would consider critical to all aspects of life. As such, educational institutions at all levels around the world are being constantly challenged to provide curriculum and educators to meet these challenges, with UNESCO (2021) reporting that ICT positively impacts student learning when their teachers are digitally 
literate and understand how to integrate ICT into the curriculum. In Thailand, preservice teachers are frontline in training the innovators and leaders of tomorrow's workforce, with numerous studies and reports outlining the critical importance of preparing these students with $21^{\text {st }}$ Century workforce skills (Buabeng-Andoh, 2012).

Unfortunately, like most creative and useful tools, there is often a dark side if not properly embraced and used, with the Internet particularly so. Most are familiar with the countless stories of Internet-related addictions and social problems in many forms, including gaming, cyberbullying, stalking, gambling, pornography, and hacking (Chao \& Yu, 2017; Castiglione, 2008; Jeong et al., 2016; Minegishi, 2020; Mishra et al., 2014; Stodt et al., 2016).

With the cyber world frequently mimicking the 'real-world', educators must, therefore, be prepared to meet these challenges head-on in their daily interactions with their students and colleagues in this cyber-world. Also, teachers and instructors must be able to acquire the skills to recognize where the pitfalls are and how to deal with them. As such, the topic of AIUB is rising in importance, especially in the training of pre-service teachers who are the educators of tomorrow.

Given these factors, it was determined better analysis and clarification were required at determining just what were the factors contributing to a Thai pre-service teacher's AIUB. Pre-service teachers as a collective are also very familiar with the Internet and social media today and are thus expected to use these technology mediums professional cares in teaching and life. Therefore, it was decided that an excellent analytical tool for use in the analysis of AIUB was the creation and analysis of a causal relationship model for pre-service teachers across Thailand. Moreover, according to Nelson (2017), preservice teacher mentors play a crucial role in how much or how little technology a preservice teacher will use in their classroom of the future.

By using a causal relationship in an HLM, researchers have the advantage of being able to parse the data at each level the data is collected from (Niehaus et al., 2014). This process also provides the findings on the influence of independent variables on the dependent variables at each level. Therefore, a pre-service teacher's AIUB is considered an essential behavioral characteristic that needs to be investigated to assess their level of AIUB, the aspects which contribute to it, and how these variables are interrelated.

For these reasons, we would like to study AIUB in Thai pre-service teachers from which HLM causal relationship models are planned. An HLM is proposed for the study as it is an excellent tool for data analysis, which enables unbiased estimates by accounting for the correlated residuals of subjects clustered at higher levels of aggregation (Booth \& Crouter, 2008). Expressed another way, HLM is useful when the data is nested in groups, such as students in classrooms within schools (Niehaus et al., 2014), as is the case in this proposed study. Also, an HLM allows the analysis of the data at separate levels, which helps in finding the effects of the dependent and independent variables at each level. Thus, for the proposed study we identified two levels of independent variables, with one at the unit level or pre-service teacher level, and the second at the group school level. Also, independent variables involved with pre-service teacher 
internal and external variables were examined (Chen, 2010), with each pre-service teacher's background investigated as independent variables, while AIUB was the dependent variable. Furthermore, it was believed that a deeper analysis was needed in which pre-service teachers should be analyzed based on their areas of specialty, which we divided into two primary subgroups of ICT and non-ICT-related disciplines.

Furthermore, other related studies have suggested that a pre-service teacher's behavior causes can be discussed in terms of both internal and external factors (Pandee et al., 2020; Sunthonkanokpong \& Murphy, 2019). Other scholars have detailed the importance of factors related to pre-service teacher ICT use (Afshari et al., 2009). In Indonesia, Benty et al. (2020) further stated that it is the educator's responsibility to assure that learning activities do not lose their essence and that students are guided in helping them in both achieving academic skills as well as using ICT in an appropriate way that is following the values and culture that exist in society. Therefore, from the study's proposed examination of pre-service teacher AIUB, it is hoped that the findings will help in giving valuable information and new knowledge helpful to the development planning of pre-service teacher AIUB.

\section{Literature Review}

\section{Appropriate Internet use Behavior (AIUB)}

In recent years the discussion concerning AIUB has increased, with various studies from around the world reporting on its importance. In Italy, Borca et al. (2015) examined how Italian adolescents used the Internet and how it affected their development. In most positive findings the authors stated that the Internet helps teens develop their interests, while also helping to identify with others and at the same time differentiate from others. The Internet is also an arena in which adolescents develop and practice autonomy, but it can also bring teens closer to their parents. Finally, respondents also felt that the Internet was an excellent tool to use in forming close relationships with peers.

UNESCO (2021) has also reported that ICT skills and use of the Internet create higherorder thinking skills, provide creative and individualized options for students to express their understandings, and leave students better prepared to deal with ongoing technological change in society and the workplace. This is consistent with a large survey of Taiwanese high school students in which it was stated that the Internet provides new information, social-related information, and social networking opportunities for Tawiwanse adolescents (Chao \& Yu, 2017), with these platforms creating a sense of solidarity and identity amongst the adolescents that use them (Palladino et al., 2015).

Moreover, past studies have shown that educators who embrace the use of the Internet, increase their support and benefits from their local community while also facilitating better interpersonal exchanges between teachers and parents (Khlaif, 2018; Schmitt et al., 2018). Also, according to Foster et al. (2018), digitally literate teachers tend to use Internet resources in creative ways, including online games, virtual reality simulations, and digital multimedia resources., which improved the quality of the overall instruction they provide. One creative method is the use of the Internet and mobile technologies such as smartphones and tablets which have great potential for facilitating more 
innovative educational methods (Sung et al., 2016). Simultaneously, these new devices and processes in educational methods are helping with student subject content learning, communications development, problem-solving, creativity, and other high-level skills among students.

\section{Inappropriate Internet use Behavior (IIUB)}

Borca et al. (2015) has reported that although the Internet can be useful in many ways, it can also be a source of conflict between parents and their children as parents are often concerned about excessive Internet use. This parental concern is supported by other studies in which Toh et al. (2017) investigated the increased use of mobile touch screen devices (MTSDs) and the growing concerns that their use may have negative musculoskeletal consequences, including eye-site strain and carpal tunnel syndrome. Mishra et al. (2014) also added that Internet addiction can harm student academic achievement.

Stodt et al. (2016) has also reported dysfunctional Internet use (DIU) and cyberbullying, stating that younger users are more prone to DIU. In both Korea and Japan, cyberbullying has become a great concern to many with several high-profile deaths of young women making headlines across the region (Minegishi, 2020). In Taiwan, Chao and $\mathrm{Yu}$ (2017) investigated cyberbullying behaviors of 13,864 Taiwanese adolescents from 150 high schools and discovered that cyberbullying was most likely to occur between 10:00-14:00. Therefore, parents and schoolteachers should pay special attention to students using the Internet during this time frame.

\section{Research objectives}

The primary purpose of the research is the development of an HLM to examine the multiple HLM levels of AIUB amongst Thai pre-service teachers, classified by both ICT and non-ICT fields of study.

\section{Research conceptual framework}

Figure 1 outlines the proposed conceptual framework of the HLM and the causal relationships between pre-service teacher independent variables and the and the school level with variables according to AIUB (Dečman, 2015; Gümüş, 2013; Stodt et al., 2016). 


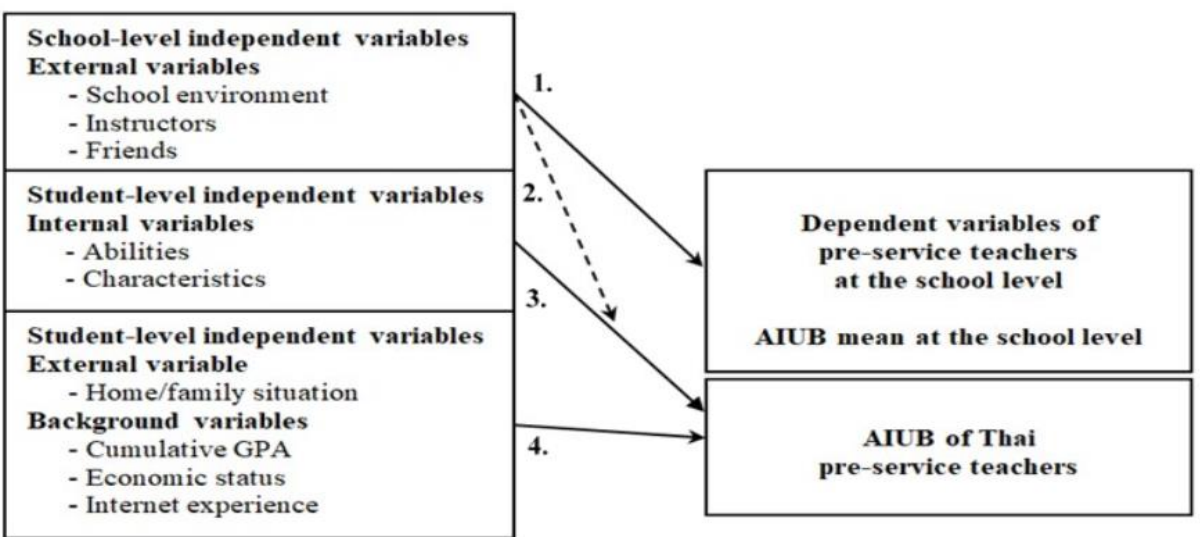

Figure 1

Conceptual framework of the HLM with two HLM levels of AIUB amongst Thai preservice teachers

Note. Solid line 1 is the same level relationship, while Line 2 (dashed line) is a crosslevel relationship (across from macro-level data to micro-level data). Line 3 is macrolevel data to macro-level data (school level), while Line 4 is micro-level data to microlevel data (pre-service teacher level).

\section{METHOD}

\section{Population and sample}

The population was undergraduate pre-service teachers at public tertiary (higher education) institutions across Thailand, from which multistage random sampling was used to select thirty tertiary institutions, from which 60 students each were selected. This represented a final sample size of 1,800 individuals.

Furthermore, the study classified the pre-service teachers into subgroups consisting of 900 individuals in ICT-related programs with another 900 individuals in non-ICT programs. Further subgroup classification was also achieved in that 900 of the study's participants came from one of 15 Thai Rajabhat universities (38 total in Thailand in 2020), which were originally established as teacher training institutions (Yin et al., 2015). Another subgroup of 900 was selected from 15 public university Faculties of Education (Table 1).

\section{Step 1}

The first step in the sample selection process included selecting a sample group from each of the Rajabhats and state university's Faculty of Education. The stratified random sampling was classified by type of educational institution into two groups. These were (a) Thai Rajabhat Universities and, (b) other state tertiary institutions, with 15 participants per group, totaling 30 individuals. 
Step 2

In the second step, simple random sampling was used from Step 1's process to select 60 pre-service teachers from each higher education institute for the study. This consisted of 900 individuals from 15 Rajabhat Universities (60 pre-service teachers each), and 900 participants from 15 state universities (60 pre-service teachers each). This represented 1,800 in total, equally divided into ICT and non-ICT program specialties (Table 1).

Table 1

Number of pre-service teachers classified by institutional type and field of study

\begin{tabular}{|c|c|c|c|c|c|}
\hline \multirow[b]{2}{*}{$\begin{array}{l}\text { Educational Institution } \\
\text { Classification }\end{array}$} & \multirow[b]{2}{*}{$\begin{array}{l}\text { Number of } \\
\text { Universities }\end{array}$} & \multirow[b]{2}{*}{$\begin{array}{l}\text { Number of } \\
\text { students per } \\
\text { university }\end{array}$} & \multicolumn{2}{|c|}{ Field of study } & \multirow[b]{2}{*}{ Total } \\
\hline & & & $\begin{array}{l}\text { ICT } \\
\text { Program } \\
\text { Students }\end{array}$ & $\begin{array}{l}\text { Non-ICT } \\
\text { Program } \\
\text { Students }\end{array}$ & \\
\hline Rajabhat Universities & 15 & 60 & 450 & 450 & 900 \\
\hline Public Universities & 15 & 60 & 450 & 450 & 900 \\
\hline Total & 30 & 60 & 900 & 900 & 1,800 \\
\hline
\end{tabular}

\section{Research instruments}

The data collection tools were questionnaires on AIUB and related data, which we created by ourselves, covering both independent and study variables. The study was developed and further modified from the pre-service teacher questionnaire on electronic learning behavior and related information (Dečman, 2015; Gümüş, 2013; Stodt et al., 2016) to cover the variables studied, consisting of the following two parts:

Part 1

The study identified three primary sub-areas in AIUB education. This included instructor-led education, Internet use for subject learning, and Internet use for informal learning. Furthermore, we identified five sub-areas in AIUB which included; (a) not violating the privacy of others, (b) not violating other's ownership, (c) not infringing on others, (d) self-protection of personal channels, and (e) being careful not to adversely affect oneself.

\section{Part 2}

Information collected for this section of the analysis includes data concerning each preservice teacher's abilities, characteristics, and general information about each pre-service teacher (Tezci, 2011). There was also information about their home/family situation, their friends/classmates/classmates, schools, and instructors. Each item was evaluated by using a six-level rating scale, with each preservice teacher's general information making use of a fill-in-the-blank format.

The questionnaire was examined for content validity by expert reviewers. After this, questionnaire reliability vetting was accomplished by the use of a pilot-test consisting of 102 undergraduate trainee teachers, who subsequently did not participate in the final study. The results of the calculations showed that Cronbach's reliability value $\alpha$ was between $0.83-0.96$ (Table 2). 
Table 2

Pilot-test reliability $(\alpha)$ of questionnaires classified by variables

\begin{tabular}{|c|c|c|c|c|}
\hline \multirow[b]{2}{*}{ Variables } & \multirow[b]{2}{*}{ Items } & \multicolumn{3}{|l|}{ Reliability $(\alpha)$} \\
\hline & & $\begin{array}{l}\text { ICT group } \\
(\mathrm{n}=51)\end{array}$ & $\begin{array}{l}\text { Non-ICT } \\
\text { group }(n=51)\end{array}$ & $\begin{array}{l}\text { Total } \\
\text { individuals } \\
(\mathrm{n}=102)\end{array}$ \\
\hline $\begin{array}{l}\text { Appropriate Internet use behaviour } \\
\text { (AIUB) }\end{array}$ & 60 & 0.93 & 0.90 & 0.92 \\
\hline Abilities & 20 & 0.93 & 0.90 & 0.92 \\
\hline Characteristics & 32 & 0.85 & 0.90 & 0.88 \\
\hline Home/family situation & 8 & 0.84 & 0.82 & 0.83 \\
\hline School environment & 17 & 0.96 & 0.93 & 0.96 \\
\hline Instructors & 9 & 0.89 & 0.84 & 0.87 \\
\hline Friends/classmates/classmates & 10 & 0.93 & 0.84 & 0.89 \\
\hline
\end{tabular}

Note. A more expansive list of the 156 pilot-test questionnaire items can be found in the Appendix.

\section{Data collection}

Research assistants used each institution's researcher network to collect a sample of 1,800 undergraduate pre-service teacher surveys. As a Thai government-funded study, participation was excellent and well supported across all 30 tertiary institutions surveyed. Fifteen of the schools selected were Rajabhat universities, and another 15 were Thai government accredited public universities. In previous years, 'Rajabhats' were referred to as institutions whose primary task was teacher education. Subsequently, in 2005 the now-deceased King Bhumibol Adulyadej the Great collectively elevated the Rajabhat teacher training colleges to university status.

From these two university system groups, the research teams were tasked with collecting 30 pre-service teachers from each school's ICT-related disciplines and 30 pre-service teachers from each school's non-ICT-related disciplines. Therefore, 900 individuals were chosen from 15 Rajabhat universities and 900 individuals from 15 Thai public universities. There was a $100 \%$ return of questionnaires as participation was highly suggested.

\section{Pre-service teacher level}

From the literature, we determined that at the pre-service teacher level, there were three main categories of variables. These included the internal variables which were identified as making up each pre-service teacher's psychological traits, including their abilities and characteristics (Buabeng-Andoh, 2012). Additionally, we feel that a pre-service teacher's environment acts as an external variable (Eksail \& Afari, 2020). Therefore, we identified their home/family situation for the analysis (Booth \& Crouter, 2008). Finally, there are background variables that are speculated as contributing to each individual's AIUB. These include their cumulative GPA scores (Cheng et al., 2012), their economic status, and their individual Internet experience (Tarawneh \& Allahawiah, 2014). 


\section{The pre-service teacher's school level}

At the school level, various factors can affect how a pre-service teacher uses the Internet. From the literature, we identified the pre-service teacher's school environment, their instructors (Nelson, 2017), and their friends or classmates (Sangrà \& GonzálezSanmamed, 2010). Also, numerous studies have pointed out the importance of Internet self-efficacy which is the pre-teacher's confidence in their mastery and performance in emerging trends and their ability to solve problems and achieve goals (Teo et al., 2019). In Taiwan, Hsu et al. (2020) also added the importance of self-efficacy and attitudes as related factors in early childhood educator's Internet-related instructional approaches. In South Korea, Hwang (2021) added that an educator's internet self-efficacy influences their instructional internet use and also improves the quality of the instruction they provide.

\section{Data analysis}

Research for the study of AIUB made use of HLMs and multilevel analysis, to classify variations of variables at the data structure level. The study also was structured to assist with the identification of relationships between variables at the same level, as well as interactions between these variables at different levels.

IBM's SPSS 21 program was used to analyze pre-service teacher AIUB, which included the $(\bar{x})$ and standard deviation (SD) statistics. Interpretation of the $\left(\bar{x}^{\bar{x}}\right)$ similarly used the following criteria to Ayçiçek and Yelken (2018):

$\begin{array}{ll}\text { Range } & \text { Behaviour Level } \\ 5.50-6.00 & \text { Very appropriate } \\ 4.50-5.49 & \text { Appropriate } \\ 3.50-4.49 & \text { Fairly appropriate } \\ 2.50-3.49 & \text { Fairly inappropriate } \\ 1.50-2.49 & \text { Inappropriate } \\ 1.00-1.49 & \text { Very inappropriate }\end{array}$

Furthermore, the HLM 7 statistical package was used for the analysis of three variations of a two-tiered linear model related to the pre-service teacher's AIUB. The details of the three models are as follows:

The fully unconditional model

This is a model of the dependent variables according to pre-service teacher AIUB.

The unconditional model

This model is a 2-level model in which only the first-level independent variable was used, which are the same level as the variables herein, are student-level, are forecasted variables. Only the independent variables that had a statistically significant influence on the dependent variable were selected $(\mathrm{p} \leq .05)$.

The hypothetical model 
This consisted of a 2-level model with independent variables at both level 1 (students) and level 2 (schools). The forecast variable criteria for the interpretation of the prediction coefficient $\left(\mathrm{R}^{2}\right)$ of the set of independent variables towards the dependent variable in the unconditional model analysis (student-independent variable model) and hypothetical model (student-level independent variables and school level model) are shown in Table 3. Moreover, $\mathrm{R}^{2}$ is the prediction coefficient, which shows the influence of independent variables (abilities, economic status, etc.) on the dependent variable (AIUB)

Table 3

Criteria for model assessments

\begin{tabular}{lll}
\hline Predictive Coefficient $) \mathrm{R}^{2}($ & Percentage $(\%)$ & Predictive level \\
\hline $\mathrm{R}^{2} \geq 0.49$ & From 49 & High \\
$0.09 \leq \mathrm{R}^{2}<0.49$ & From 9 but lower than 49 & Moderate \\
$\mathrm{R}^{2}<0.09$ & Lower than 9 & Low \\
\hline
\end{tabular}

Source: (Croucher, 2016, p. 71; Moore et al., 2021, Chapter 18).

\section{FINDINGS}

Tables $4-7$ show the results of the IBM SPSS Version 21 descriptive statistics and relationship analysis amongst the variables that were determined to correlate with appropriate internet use behavior of pre-service teachers.

Table 4

Description of the participants

\begin{tabular}{|c|c|c|c|c|}
\hline \multirow{2}{*}{ Description } & \multicolumn{2}{|l|}{ ICT group } & \multicolumn{2}{|c|}{ Non-ICT group } \\
\hline & Individuals & Percent & Individuals & Percent \\
\hline \multicolumn{5}{|l|}{ Gender } \\
\hline - Male & 461 & 51.22 & 439 & 48.78 \\
\hline - Female & 439 & 48.78 & 461 & 51.22 \\
\hline \multicolumn{5}{|c|}{$\begin{array}{l}\text { Place where pre-service teachers use the internet for } \\
\text { learning most }\end{array}$} \\
\hline - Home / other accommodations & 607 & 67.44 & 572 & 63.56 \\
\hline - University & 189 & 21.00 & 202 & 22.44 \\
\hline - Computer cafe & 75 & 8.33 & 101 & 11.22 \\
\hline - Friend or classmate's house & 9 & 1.00 & 14 & 1.56 \\
\hline - Other (malls, transportation, etc.) & 20 & 2.22 & 11 & 1.22 \\
\hline \multicolumn{5}{|c|}{ Frequently searched pre-service teacher information } \\
\hline - Text & 127 & 14.11 & 130 & 14.44 \\
\hline - Images & 60 & 6.67 & 42 & 4.67 \\
\hline - Music/audio & 29 & 3.22 & 43 & 4.78 \\
\hline - Text and images & 297 & 33.00 & 352 & 39.11 \\
\hline - Audio and Video & 183 & 20.33 & 177 & 19.67 \\
\hline - Multimedia & 204 & 22.67 & 156 & 17.33 \\
\hline \multicolumn{5}{|l|}{ Cumulative GPA } \\
\hline - Below 1.50 & 3 & 0.33 & 10 & 1.11 \\
\hline$-1.50-1.99$ & 25 & 2.78 & 28 & 3.11 \\
\hline$-2.00-2.49$ & 127 & 14.11 & 96 & 10.67 \\
\hline$-2.50-2.99$ & 272 & 30.22 & 240 & 26.67 \\
\hline$-3.00-3.49$ & 349 & 38.78 & 393 & 43.67 \\
\hline
\end{tabular}




\begin{tabular}{lllll}
\hline \multirow{2}{*}{ Description } & \multicolumn{2}{l}{ ICT group } & \multicolumn{2}{l}{ Non-ICT group } \\
\cline { 2 - 5 } & Individuals & Percent & Individuals & Percent \\
\hline$-3.50-4.00$ & 124 & 13.78 & 133 & 14.78 \\
\hline
\end{tabular}

Table 5

The ${ }^{\bar{x}}, \mathrm{SD}$, kurtosis (Kurt), and skewness (Skew) of the variables

\begin{tabular}{lllllllll}
\hline \multirow{2}{*}{ Variables } & \multicolumn{7}{l}{ ICT group } & \multicolumn{7}{c}{ Non-ICT group } \\
\cline { 2 - 9 } & $\bar{x}$ & SD & Skew & Kurt & $\bar{x}$ & SD & Skew & Kurt \\
\hline AIUB & 4.86 & .52 & -.63 & .47 & 4.86 & .53 & -.83 & .74 \\
\hline Abilities & 4.86 & .60 & -.79 & 1.22 & 4.86 & .61 & -.63 & .49 \\
\hline Characteristics & 4.61 & .65 & -.51 & .78 & 4.55 & .66 & -.16 & -.34 \\
\hline Home/Family situation & 4.61 & .84 & -1.08 & 1.77 & 4.59 & .89 & -.91 & 1.10 \\
\hline Economic status & $5,898.872,723.471 .60$ & 4.24 & $6,621.503,119.281 .45$ & 3.41 \\
\hline Internet experience & 8.26 & 3.27 & .336 & -.388 & 8.88 & 3.39 & .053 & -.597 \\
\hline School environment & 4.38 & .86 & -.96 & 1.11 & 4.33 & .91 & -.81 & .70 \\
\hline Instructors & 4.70 & .66 & -.71 & .83 & 4.64 & .73 & -.77 & 1.12 \\
\hline Friends/classmates/classmates & 4.86 & .72 & -.14 & 4.66 & 4.88 & .72 & -.98 & 1.43 \\
\hline
\end{tabular}

Table 6

Level 1 non-ICT group independent variable correlations

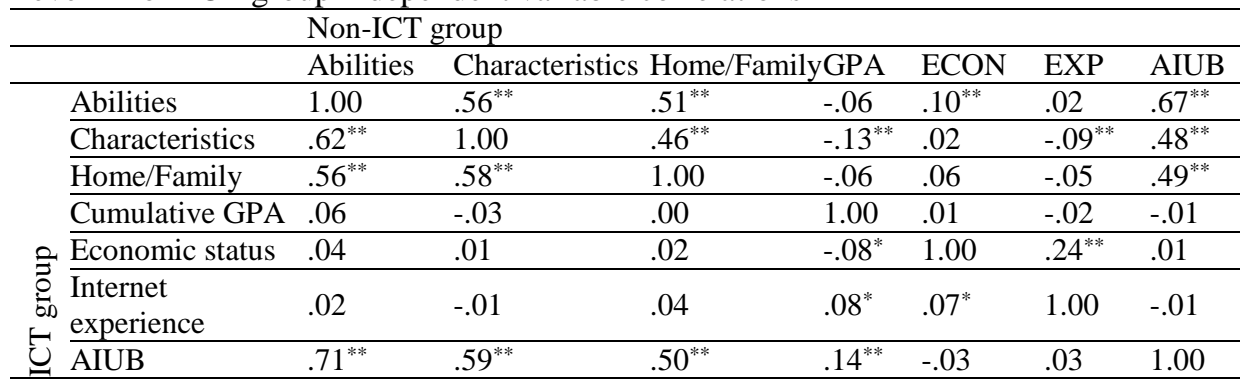

Note. $* p \leq 0.05, * * p \leq 0.01$.

Table 7

Level 2 ICT group independent variable correlations

\begin{tabular}{clllll}
\hline \multicolumn{5}{c}{ Non-ICT group } & \\
\hline & Schools & Instructors & Friends/classmates AIUB \\
\hline \multirow{2}{*}{} & Schools & 1.00 & $.76^{* *}$ & -.11 & -.02 \\
\cline { 2 - 6 } & Instructors & $.84^{* *}$ & 1.00 & .05 & .00 \\
\cline { 2 - 6 } & Friends/classmates & -.09 & .12 & 1.00 & $.83^{* *}$ \\
\cline { 2 - 6 } & AIUB & -.04 & .13 & $.87^{* *}$ & 1.00 \\
\hline
\end{tabular}

Note. $* * p \leq 0.01$.

The HLM 7 software program was used to analyze the two-tiered linear model for appropriate internet use behavior of Thai pre-service teachers. As such, three types of two-tier models were evaluated. These included a model with a dependent variable, a 
second model with student-level independent variables, and a third model using independent variables at the school and student levels (Figures $2-3$ ).

Additionally, Figure 2 shows the HLM levels for AIUB for ICT group pre-service teachers, which consisted of five statistically significant predictor variables at both levels, four of which were the pre-service teacher student-level variables of abilities $(\mathrm{b}=$ $0.312)$, characteristics $(\mathrm{b}=0.140)$, home/family situation $(\mathrm{b}=0.117)$ and cumulative GPA. The one variable at the school level was friends/classmates $(\mathrm{b}=0.079)$, with it directly predicting the mean behavior of the pre-service teachers.

Beta (b) is a beta coefficient value that indicates whether an independent variable (abilities, economic status, etc.) has more or less influence on the dependent variable (AIUB). Beta-weights are also standardized coefficients, which are essentially expressed as z-scores (or standard deviation units) (Fernández-Castilla et al., 2019). The advantage of this process is that all coefficients are expressed in the same units. Thus, the coefficients can be compared one to another to determine which variable carries the most 'weight' or influence in predicting the dependent variable.

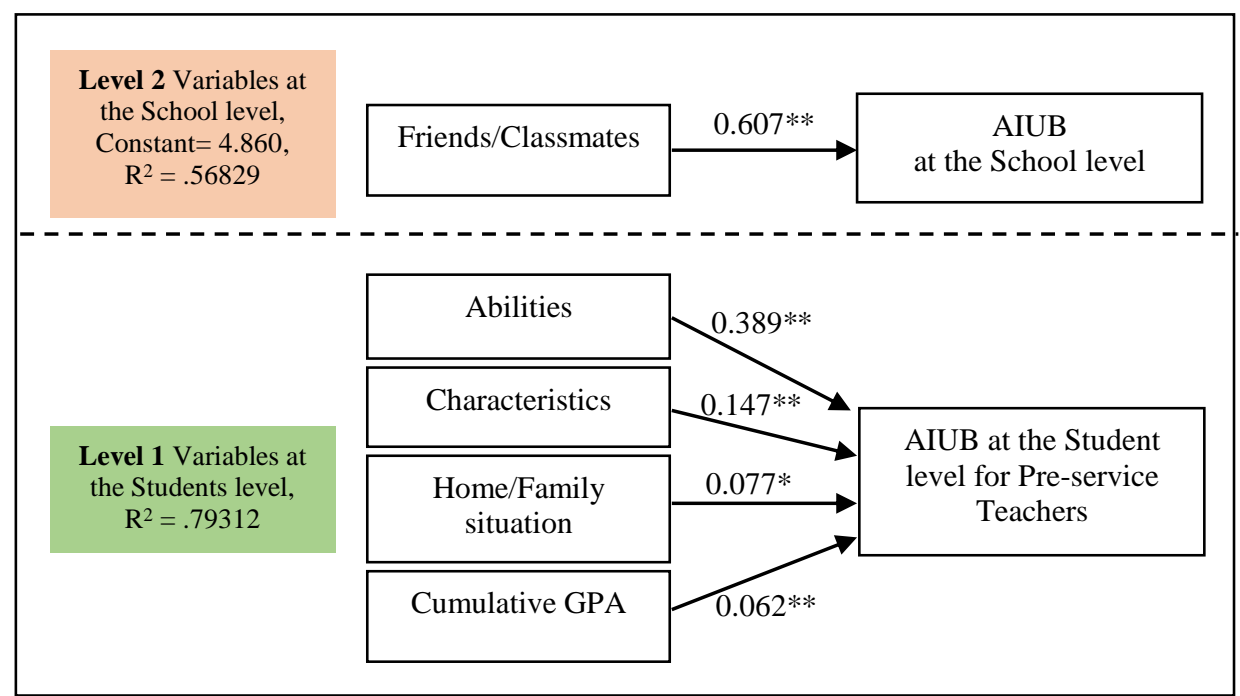

Figure 2

The Two-Tiered Linear Model for the ICT Pre-Service Teacher AIUB Group Note. $* p \leq 0.05, * * p \leq 0.01$.

Figure 3 shows the multiple-level HLM for AIUB for non-ICT group pre-service teachers, with five statistically significant predictor variables at both levels, including four student-level variables, namely abilities $(b=0.369)$, characteristics $(b=0.137)$, home/family situation $(b=0.120)$, and economic status. At the school level was one variable of friends/classmates $(b=0.250)$, where the peer variable directly predicted the mean behavior of the pre-service teachers. School variables were indirectly forecasted through the competency variables of the pre-service teacher. In Table 8 the pre-service 
teachers AIUB independent variables are shown classified by their subject group at both the student and school levels

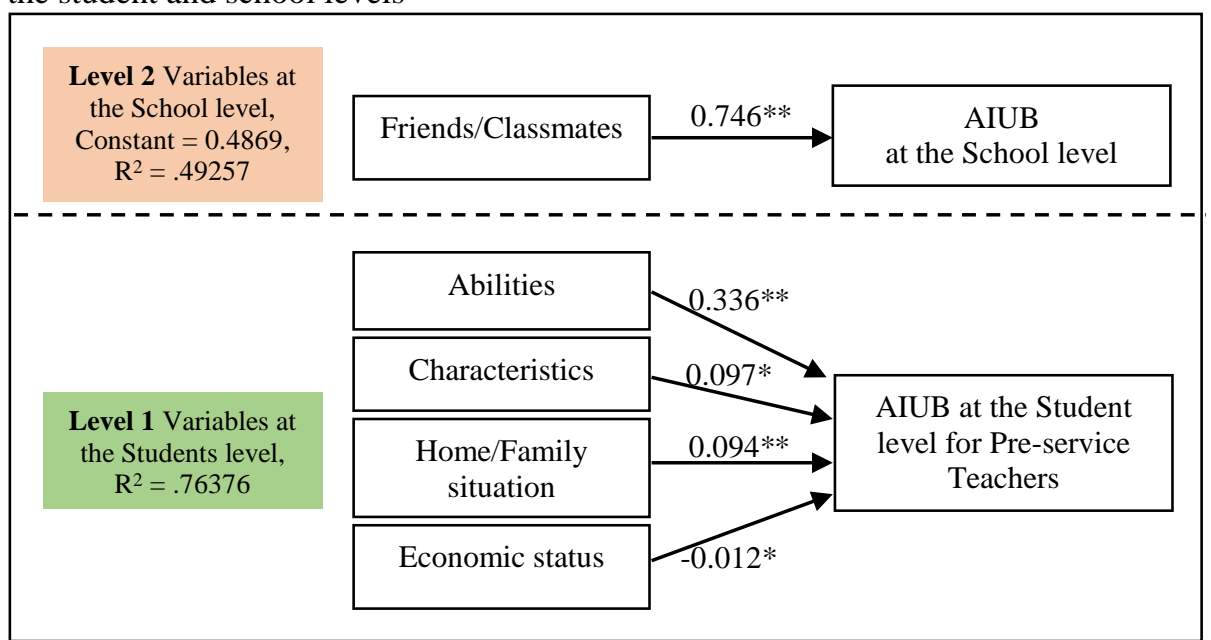

Figure 3

The Two-Tiered Linear Model for the non-ICT Pre-Service Teacher AIUB Group Note. $* p \leq 0.05, * * p \leq 0.01$.

Table 8

Pre-service teacher AIUB independent variables classified by the subject group at both the student and school levels

\begin{tabular}{lll}
\hline \multirow{2}{*}{ Independent variables } & Disciplines & \\
\cline { 2 - 3 } Level 1 Student Level & ICT group & non-ICT group \\
\hline - Abilities & & \\
\hline - Characteristics & $\mathrm{I}$ & $\mathrm{I}$ \\
\hline - Home/family situation & $\mathrm{I}$ & $\mathrm{I}$ \\
\hline - Gender & $\mathrm{I}$ & $\mathrm{I}$ \\
\hline - Age & $\mathrm{N}$ & $\mathrm{N}$ \\
\hline - Field of study & $\mathrm{N}$ & $\mathrm{N}$ \\
\hline - Cumulative GPA & $\mathrm{N}$ & $\mathrm{N}$ \\
\hline - Economic status & $\mathrm{I}$ & $\mathrm{N}$ \\
\hline - Internet experience & $\mathrm{N}$ & $\mathrm{I}$ \\
\hline Level 2, School Level & $\mathrm{N}$ & $\mathrm{N}$ \\
\hline - School environment & & \\
\hline - Instructors & $\mathrm{N}$ & $\mathrm{N}$ \\
\hline - Friends/classmates & $\mathrm{N}$ & $\mathrm{N}$ \\
\hline
\end{tabular}


Note. $I=$ influential, $N=$ not influential

\section{DISCUSSION}

It was found that each preservice teacher's abilities and characteristics (internal variables), and their home/family situation and friends/classmates (external variables) were predictive parameters that influenced the two models, confirming the importance of these four internal and external variables as a factor that positively influences AIUB. These findings are consistent with other studies in which it has been suggested that students use information about situations to moderate and shape their behavior (Pimdee, 2021). Additionally, students learn from observing others surrounding them, through the use of media, their friend's influence, and their family (Asmuni et al., 2012).

Moreover, further analysis of the two-tiered linear model of AIUB for both groups of disciplines determined that there were a total of five forecasting variables. Specifically, these were four student-level forecasting variables, including abilities (0.389), characteristics (0.147), home/family situation (0.077), and cumulative GPA (0.062), with a combined positive predictive variance of AIUB in pre-service teachers at $57 \%$. These results from our study are consistent with other studies in which GPA has also been reported to play a positive role in AIUB (Mishra et al., 2014). However, if Internet use is not controlled, it can harm a student's academic work (Mishra et al., 2014).

Furthermore, at the school level, the forecasting variable of friends/classmates (0.607) was able to predict the mean of AIUB at a rate of $79 \%$, which indicates its strong and positive influence on AIUB. Today, social media has taken on critical importance in the vast majority of all university students. Thus, friends/classmates play a paramount role in suggesting and the use of AIUB. Therefore, schools and universities must promote teacher networking and provide resources and facilities to help with AIUB (Ansari \& Khan, 2020). This is consistent with Afshari et al. (2009), which also reported that enhancing the teaching-learning process requires new pedagogies and learning obtained from ongoing professional development.

Next, from the two-tiered linear model of pre-teacher AIUB for the non-ICT group, it was determined that a total of four forecasting variables were statistically significant. These included the four student-level forecasting variables of abilities (0.336), characteristics (0.097), home/family situation (0.094), and economic status (-0.012). Combined, these four variables accounted for a $49 \%$ positive influence on AIUB. However, the only exception was the variable economic status that had a negative influence on AIUB, which contributed to our conclusion that lower-economic status students behave more appropriately than higher-economic status students. Finally, it was determined that at the school level, the forecasting variable of friends/classmates $(0.746)$ can predict the mean of AIUB with $73 \%$ reliability.

\section{CONCLUSION}

This study set out to report on Thai preservice teachers' appropriate Internet use behavior (AIUB) in 30 tertiary institutions across Thailand. Three types of two-tier HLMs were evaluated, one with a dependent variable, a second model with student-level 
independent variables, and a third model using independent variables at both the student level and the school level. Moreover, the three HLMs were classified by ICT and nonICT disciplines in which the results revealed that each preservice teacher's abilities, characteristics, home/family situation, and their friends/classmates were predictive parameters that influenced the models, confirming the importance of these four variables in positively influencing preservice teacher AIUB.

\section{SUGGESTIONS}

Educational policymakers at every level need to focus on the development of school readiness. This includes educational personnel development, both for the school administrators and their teachers. They must also be able to jointly develop students and teachers in effective AIUB processes.

Schools need to also have physical readiness in the form of computer labs, highperformance Internet networking, and smart classrooms. There also needs to be readiness training of staff, teachers, and administrators, which includes the organization of projects and activities that promote Internet use learning and ethical use of the Internet by teachers.

Teachers should improve teaching quality by assigning tasks that can lead to AIUB. Suggested areas include ethical use of the Internet, related advice, resources, and how to work, as well as assessing student performance fairly and giving feedback to students and other teachers. Teachers should provide Internet-based learning experiences in a format that allows students, teachers, and their peers to interact in a way that fosters mutual learning, such as cooperative learning and STEM study.

When and where possible, families of both teachers and students should take an active role in supporting and promoting AIUB on home computers, the Internet and social media platforms, and smartphones.

Greater attention needs to be taken by pre-service teachers on their self-learning abilities, their self-development, their Internet use patterns, and what media they select. They should also consider the ethics of their Internet use while building relationships with classmates that promote mutual learning. Finally, more advanced individuals should assist their classmates in obtaining and developing their competencies and skills.

\section{LIMITATIONS AND FUTURE RESEARCH}

As this study focused on only university preservice teachers, there is a limitation concerning the results' focus to this age group only. Therefore, follow-on studies should investigate how students at other levels and age groups approach AIUB. Moreover, the study was limited in its focus on preservice teacher training institutions and their related programs. Given the Thai government's push for a new digital economy and the importance placed on vocational education graduates within the new 'Thailand 4.0' environment, other studies should investigate how the Internet plays a role within this educational sector and what factors play a part in the Internet's appropriate or inappropriate use by both students and teachers. Moreover, further expansion of the 
study's sub-groups should be considered due to the limitations of the school locations. Future studies might also want to compare rural to urban campuses and the school's size. This might assist in identifying vulnerable groups who still have IIUB and ways to find more AIUB. Smart classrooms should also be developed in which Internet learning materials are used to stimulate/motivate students in more appropriate learning. Development of a model for parents to have better knowledge and awareness of the importance of using the Internet for learning, as well as the issues concerning its ethical use. It would be useful to both academics and administrators alike if a study was compiled in which the best practices of schools with good practices contributing to the development of internet-based learning behavior of students and teachers disseminated and/or readily accessible. Thus, this might contribute significantly to all participants in having a better precept on how to better develop Internet learning behavior for everyone.

\section{REFERENCES}

Afshari, M., Bakar, K. A., Luan, W. S., Samah, B. A., \& Fooi, F. S. (2009). Factors affecting teachers' use of information and communication technology. International Journal of Instruction, 2(1), 77-104. https://tinyurl.com/y74fvugh

Ansari, J. A. N., \& Khan, N. A. (2020). Exploring the role of social media in collaborative learning the new domain of learning. Smart Learning Environments, 7 , 9(2020). https://doi.org/10.1186/s40561-020-00118-7

Asmuni, S., Khalili, J. M., \& Zain, Z. M. (2012). Sustainable consumption practices of students in an urban settings: A case in Selangor. Procedia - Social and Behavioral Sciences, 36, 716-722. https://doi.org/10.1016/j.sbspro.2012.03.078

Ayçiçek, B., \& Yelken, T. Y. (2018). The effect of flipped classroom model on students' classroom engagement in teaching English. International Journal of Instruction, 11(2), 385-398. https://doi.org/10.12973/iji.2018.11226a

Benty, D. D. N., Mustiningsih., \& Maisyaroh. (2020). Training for improving the leadership of schools in the era of disruption. Advances in Social Science, Education and Humanities Research, 501, 130-134. https://doi.org/10.2991/assehr.k.201204.022

Booth, A., \& Crouter, A. C. (Eds.) (2008). Disparities in school readiness: How families contribute to transitions into school. Lawrence Erlbaum.

Borca, G., Bina, M., Keller, P. S., Gilbert, L. R., \& Begotti, T. (2015). Internet use and developmental tasks: Adolescents' point of view. Computers in Human Behavior, 52, 49-58. https://doi.org/10.1016/j.chb.2015.05.029

Buabeng-Andoh, C. (2012). Factors influencing teachers' adoption and integration of information and communication technology into teaching: A review of the literature. International Journal of Education and Development using Information and Communication Technology, 8(1), 136-155. https://tinyurl.com/yajcurxh 
Castiglione, J. (2008). Internet abuse and possible addiction among undergraduates: A developing concern for library and university administrators. Library Review, 57(5), 358-371. https://doi.org/10.1108/00242530810875140

Chao, C-M., \& Yu, T-K. (2017). Associations among different Internet access time, gender and cyberbullying behaviors in Taiwan's adolescents. Frontiers in Psychology, 8, Article 1104. https://doi.org/10.3389/fpsyg.2017.01104

Chen, R. J. (2010). Investigating models for preservice teachers' use of technology to support student-centered learning. Computers \& Education, 55(1), 32-42. https//doi.org/10.1016/j.compedu.2009.11.015

Cheng, W., Ickes, W., \& Verhofstadt, L. (2012). How is family support related to students' GPA scores? A longitudinal study. Higher Education, 64, 399-420. https://doi.org/10.1007/s10734-011-9501-4

Croucher, J. S. (2016). Introductory mathematics and statistics (6th ed.). McGraw-Hill Education Australia. https://tinyurl.com/4sea32bz

Dečman, M. (2015). Modeling the acceptance of e-learning in mandatory environments of higher education: The influence of previous education and gender. Computers in Human Behavior, 49(August), 272-281.

Eksail, F. A., \& Afari, E. (2020). Factors affecting trainee teachers' intention to use technology: A structural equation modeling approach. Education and Information Technologies, 25(4), 2681-2697. https://doi.org/10.1007/s10639-019-10086-2

Fernández-Castilla, B., Aloe, A. M., Declercq, L., Jamshidi, L., Onghena, P., Beretvas, S. N., \& Van den Noortgate, W. (2019). Concealed correlations meta-analysis: A new method for synthesizing standardized regression coefficients. Behavior Research Methods, 51, 316-331 (2019). https://doi.org/10.3758/s13428-018-1123-7

Foster, M. E., Anthony, J. L., Clements, D. H., Sarama, J., \& Williams, J. J. (2018). Hispanic dual language learning kindergarten students' response to a numeracy intervention: A randomized control trial. Early Childhood Research Quarterly, 43, 8395. https://doi.org/10.1016/j.ecresq.2018.01.009

Gümüş, S. (2013). Investigating the factors affecting information and communication technology (ICT) usage of Turkish students in PISA 2009. Turkish Online Journal of Educational Technology, 12(1), 102-107.

Hsu, P-C., Chang, I-H., \& Chen, R-S. (2020). Early childhood educators' attitudes to Internet self-efficacy and Internet-related instructional applications: The mediating effects of Internet enjoyment and professional support. SAGE Open, 10(1), 215824402091439. https://doi.org/10.1177/2158244020914390

Hwang, S. (2021). The mediating effects of self-efficacy and classroom stress on professional development and student-centered instruction. International Journal of Instruction, 14(1), 1-16. https://doi.org/10.29333/iji.2021.1411a 
Jeong, B. S., Han, D. H., Kim, S. M., Lee, S. W., \& Renshaw, P. F. (2016). Addiction Biology, 21(3), 732 - 742. https://doi.org/10.1111/adb.12246

Khlaif, Z. (2018). Teachers' perceptions of factors affecting their adoption and acceptance of mobile technology in K-12 settings. Computers in the Schools, 35(1), 4967. https://doi.org/10.1080/07380569.2018.1428001

Minegishi, H. (2020, June 7). Cyberbullying: How Japan is following in South Korea's footsteps. Nikkei Asia. https://tinyurl.com/4duw9muv

Mishra, S., Draus, P., Goreva, N., Leone, G., \& Caputo, D. (2014). The impact of Internet addiction on university students and its effect on subsequent academic success: A survey-based study. Issues in Information Systems, 15(I), 344-352. https://tinyurl.com/yce4rrmy

Moore, D. S., Notz, W. I., \& Fligner, W. (2021). The basic practice of statistics (9th ed.). MacMillan Learning.

Nelson, M. (2017). The role of a mentor teacher's TPACK in preservice teachers' intentions to integrate technology. Journal of Technology and Teacher Education, 25(4), 449-473. https://tinyurl.com/yxda5sdw

Niehaus, E., Campbell, C. M., \& Inkelas, K. K. (2014). HLM behind the curtain: Unveiling decisions behind the use and interpretation of HLM in higher education research. Research in Higher Education, 55, 101-122. https://doi.org/10.1007/s11162013-9306-7

Palladino, B. E., Nocentini, A., \& Menesini, E. (2015). Psychometric properties of the Florence cyberbullying-cybervictimization scales. Cyberpsychology, Behavior, and Social Networking, 18, 112-119. https://doi.org/10.1089/cyber.2014.0366

Pandee, M., Tepsuriwong, S., \& Darasawang, P. (2020). The dynamic state of preservice teachers' self-efficacy: A critical incident study in Thailand. Issues in Educational Research, 30(4), 1442- 462. https://tinyurl.com/ybft9p5q

Pimdee, P. (2021). An analysis of the causal relationships in sustainable consumption behaviour (SCB) of Thai student science teachers. International Journal of Instruction, 14(1), 999-1018. http://www.e-iji.net/dosyalar/iji_2021_1_59.pdf

Sangrà, A., \& González-Sanmamed, M. (2010). The role of information and communication technologies in improving teaching and learning processes in primary and secondary schools. Australasian Journal of Educational Technology, 26(8), 207 220. https://doi.org/10.14742/ajet.1020

Schmitt, K. L., Hurwitz, L. B., Duel, L. S., \& Linebarger, D. L. N. (2018). Learning through play: The impact of web-based games on early literacy development. Computers in Human Behavior, 81, 378-389. https://doi.org/10.1016/j.chb.2017.12.036

Stodt, B., Wegmann, E., \& Brand, M. (2016). Predicting dysfunctional Internet use: The role of age, conscientiousness, and Internet literacy in Internet addiction and 
cyberbullying. International Journal of Cyber Behavior, Psychology and Learning, 6(4), 28-43. https://doi.org/10.4018/ijcbpl.2016100103

Sung, Y-T., Chang, K-E., Liu, T-C., Sung, Y-T., Chang, K-E., \& Liu, T-C. (2016). The effects of integrating mobile devices with teaching and learning on students' learning performance: A meta-analysis and research synthesis. Computers \& Education, 94, 252-275. https://doi.org/10.1016/j.compedu.2015.11.008

Tarawneh, S. A., \& Allahawiah, S. R. (2014). Factors affecting information and communication technology (ICT) use by southern colleges teachers in Balqa Applied University. International Journal of Computers \& Technology, 12(10), 3983-3989. https://doi.org/10.24297/ijct.v12i10.2984

Teo, T., Sang, G., Mei, B., Hoi, C. K. W. (2019). Investigating pre-service teachers' acceptance of Web 2.0 technologies in their future teaching: A Chinese perspective. Interactive Learning Environments, 27(4), 530-546. https://doi.org/10.1080/10494820.2018.1489290

Tezci, E. (2011). Factors that influence pre-service teachers' ICT usage in education. European Journal of Teacher Education, 34(4), 483-499. https://doi.org/10.1080/02619768.2011.587116

Toh, S. H., Coenen, P., Howie, E. K., \& Straker, L. M. (2017). The associations of mobile touch screen device use with musculoskeletal symptoms and exposures: A systematic review. Plos One, 12(8), e0181220. https://doi.org/10.1371/journal.pone.0181220

UNESCO. (2021, January 11). Brief 4: Information and communication technology (ICT) in education. https://tinyurl.com/ab4rbvpu

Yin, H., Ruangkanjanases, A., \& Chen, C. (2015). Factors affecting Chinese students' decision making toward Thai universities. International Journal of Information and Education Technology, 5(3), 189-195. http://www.ijiet.org/show-52-560-1.html 


\section{APPENDIX}

Table 9

Thai AIUB Preservice teacher pilot-test questionnaire item categories

\begin{tabular}{|c|c|}
\hline Variables & Items \\
\hline 1. Appropriate Internet Use Behavior & 60 \\
\hline 1.1 Internet Learning Use Behavior & 30 \\
\hline 1.1.1 Using the Internet for learning as specified by teachers & 16 \\
\hline 1.1.2 Using the Internet to improve learning in various subjects & 7 \\
\hline 1.1.3 Using the Internet for informal learning & 7 \\
\hline 1.2 Internet Ethical Use Behavior & 30 \\
\hline 1.2.1 Respect for other Internet users' privacy & 6 \\
\hline 1.2.2 Respect for other Internet users' intellectual property & 6 \\
\hline 1.2.3 Respect for others feelings & 6 \\
\hline 1.2.4 Internet privacy and security & 6 \\
\hline 1.2.5 Being careful not to harm oneself (addiction) & 6 \\
\hline 2. Internet Use Abilities & 20 \\
\hline 2.1 Ability to learn at your own pace & 6 \\
\hline 2.2 Ability to use the Internet & 6 \\
\hline 2.3 Ability to use Internet multimedia & 8 \\
\hline 3. Internet Use Characteristics & 32 \\
\hline 3.1 Internet use attitude & 8 \\
\hline 3.2 Focusing on the future and controlling oneself & 8 \\
\hline 3.3 Internet success incentives & 8 \\
\hline 3.4 Internet reading habits & 8 \\
\hline 4. Internet Home Use Situation & 8 \\
\hline 4.1 Home Internet readiness support & 4 \\
\hline 4.2 Internet family support & 4 \\
\hline 5. Internet School Use Situation & 17 \\
\hline 5.1 School Internet availability & 5 \\
\hline 5.2 Internet educational institution service support & 5 \\
\hline 5.3 School Internet support & 7 \\
\hline 6. Internet Teachers & 9 \\
\hline 6.1 Teacher Internet assignments and homework & 3 \\
\hline 6.2 Teacher Internet advice & 3 \\
\hline 6.3 Teacher Internet evaluation & 3 \\
\hline 7. Internet Friends & 10 \\
\hline
\end{tabular}

International Journal of Instruction, January $2022 \bullet$ Vol.15, No.1 
7.1 The characteristics of Internet friends

5

7.2 Interaction with Internet friends

5 